\title{
Smart Energy Frameworks for Smart Cities: The Need for Polycentrism
}

\author{
Joseph Nyangon
}

\section{Contents}

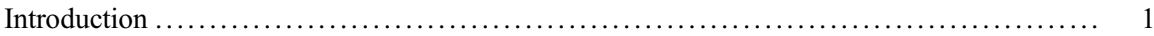

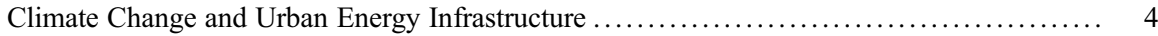

The Nature of the Challenge ............................................... 5

Smart Grid and the Future of Smart Cities ................................... 6

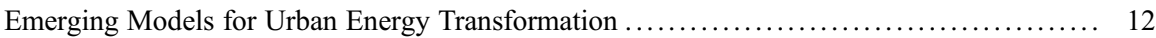

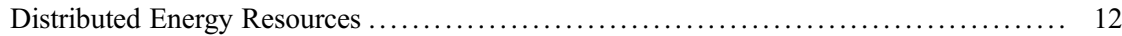

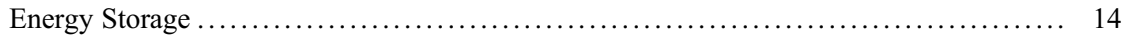

Microgrids ........................................................... 15

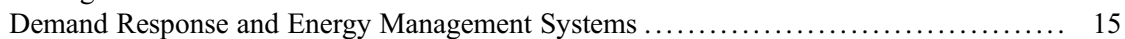

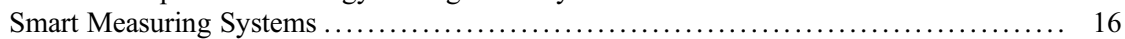

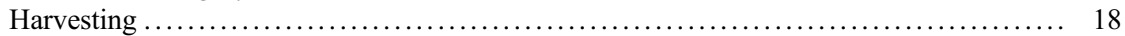

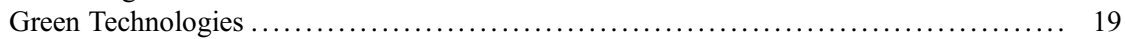

From Robustness to Resilience ........................................ 20

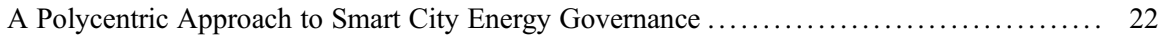

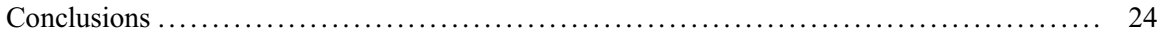

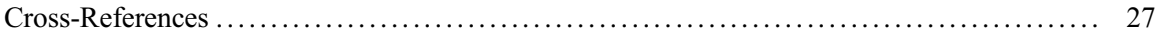

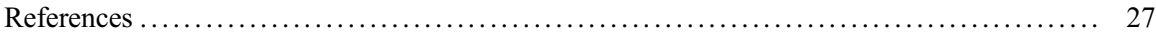

\section{Introduction}

Rapidly rising populations in cities, urbanization and economic development have prompted the emergence of megacities, i.e., urban agglomerations with populations exceeding 10 million inhabitants (Kennedy et al. 2015). Because of their sheer size and complexity, megacities present epic social, economic, and environmental

\footnotetext{
J. Nyangon ( $₫)$

Center for Energy and Environmental Policy (CEEP), University of Delaware, Newark, DE, USA e-mail: jnyangon@udel.edu
} 
challenges. In the last three decades, major cities in the United States and Europe have been prioritizing new forms of sustainable urban development, notably new urbanism, compact city models and smart urban growth through transit-oriented development to counteract these challenges (Ewing et al. 2017; Noland et al. 2017; Kim and Larsen 2017; Chhetri et al. 2013). Although these models have different origins and objectives, they generally seek to improve energy and material flows toward reduced energy- and water-use intensity, increased adoption of mass transit systems, controlled growth and expansion, mixed and diverse land-use development, and stronger urban sensibility. In the global south such as in many African and Asian cities like Cape Town, Bangalore, Bangkok, Beijing, Chennai, Guangzhou, Hong Kong, Lagos, Mexico City, Nairobi, Nanjing, and Shanghai, however, a variety of smart urban energy solutions have mainly focused on alleviating environmental pollution and the decreasing density (or, alternatively, urbanized area per capita), in part, owing to rapid population growth and rural-urban migration (Chiu 2012).

In 2014, China reported the largest urban population globally of 758 million as well as six megacities, i.e., Shanghai, Beijing, Chongqing, Guangzhou, Tianjin, and Shenzhen, and is projected to add one more megacity (Chengdu) and six more large cities (i.e., Wuhan, Dongguan, Hong Kong, Nanjing, Foshan, and Shenyang) by 2030 (United Nations 2014). This remarkable rapid growth in the size and number of megacities upends a range of social-technical transitions, institutional change, economic innovations, and scientific inquiries. The frameworks adopted to understand energy and material flows of cities, in particular, the nexus between urbanization, resilience, and resource efficiency and related synergies between jurisdictions, sectors, and technical solutions required to optimize resource management and improve institutional frameworks for effective service delivery have focused on top-bottom strategies. (Clark et al. 2019; Sircar et al. 2013). As a result, these strategies have been criticized for being ineffective, inflexible, less transparent, and inadequate in mediating the effects of socio-environmental inequalities in cities. For instance, unlike most American cities, Chinese cities are high-density areas integrated via transit-oriented development (TOD) (with high levels of mixed-land use configurations around public transport stops), making them ideal for the compact city model. The new urbanism concept thus is not ideal for the progrowth ethos of most Chinese megacities and other densely populated cities in the developing world, but rather less populated European cities which tend to emphasize a more compact urban form and smart growth as an antidote to the ills associated with urban sprawl (Wey and Hsu 2014; MacLeod 2013).

Transit-oriented development model, however, is more suitable for cities like Berlin, London, Madrid, Milan, New York, Paris and others, which have a long history of implementing mass transit systems, because it maximizes integrated access to residential, business and leisure activities within walking distance of near-excellent public transport (Noland et al. 2017). Smart, networked cities increasingly require polycentric governance of socio-technical systems that together form the elements of their energy frameworks in order to foster smart growth, accelerate low-carbon transitions, and lessen fragility concerns that emanate from a troika of 
rapid population growth, urbanization, and climate change challenges. With respect to climate change, the cost of urban infrastructure damage is rapidly rising. For instance, in August 2017, Hurricane Harvey cut a destructive path across Texas and the Gulf of Mexico leaving thousands without electricity, while in 2012, Hurricane Sandy caused extensive destruction and damage to energy infrastructure across several northeastern states (Maryland, Delaware, New Jersey, New York, Connecticut, Massachusetts, and Rhode Island) due to high wind and coastal storm surge. The U.S. National Oceanic and Atmospheric Administration (NOAA) estimates the total damage from Harvey and the 2005 Hurricane Katrina at $\$ 130$ billion and US $\$ 168$ billion (2019 consumer price index cost adjusted value), respectively, making these two events the costliest U.S. weather and climate disasters on record since 1980 (Smith 2019). As acknowledged by the Intergovernmental Panel on Climate Change (IPCC), energy infrastructure (as well as other high-quality urban infrastructure-based networked systems like transportation) is increasingly confronted with a series of grand challenges - rapid population growth, urbanization, and climate change (Revi et al. 2014). This situation is compounded by the fact that these critical urban infrastructure systems constitute the backbone of a networked city, are largely inflexible to changes in utilization and external conditions due to the spatial alignment and coevolution of their elements, are underfunded and often poorly maintained, and are increasingly complex and interconnected across several functions. (The problem is particularly acute in urban areas, where growing populations stress society's support systems and natural disasters, accidents, and terrorist attacks threaten infrastructure safety and security.) Diversifying energy systems - through the interlinked mix of clean energy technologies, institutional change, user-centered design practices, and market and regulatory innovations - can help cities achieve their low-carbon objectives, promote greater energy security and electric grid stability, and improve access to modern energy services as new energy demand is projected to take place in rapidly urbanizing metropolitan regions and megacities (Taminiau et al. 2019; Nyangon and Byrne 2018; Byrne and Taminiau 2018; Taminiau et al. 2017). Therefore, the investment decisions cities make today in high-growth intensive sectors especially infrastructure such as roads, electrical power systems, sewers, and buildings will influence the evolution of urban spatial structure and their socio-environmental dynamics for several decades.

Different types of urban systems, for example, compact, well-connected cities versus sprawling, car-dependent urban locations, can act as straightjackets for smart cities of the future by providing integrated and resilient energy frameworks and metrics for addressing known and unknown challenges. Such efforts entail increasing momentum of niche innovations, weakening existing legacy systems, and strengthening exogenous trends and developments, which when aligned can destabilize the existing system to create processes that yield breakthrough innovations (Nyangon 2017). While the potential benefits of smart energy networked cities exist in smart investments such as energy management services, energy storage, distributed energy resources, demand-side management, and automatic measurement and verification, poorly managed urban growth does have social and economic costs. 
This chapter proposes reorienting the principles and tenets of energy business models and frameworks toward a polycentric approach by focusing on six key imperatives: (a) stakeholder-driven approach, (b) enhanced accountability and legitimacy, (c) inclusivity and equitability, (d) adaptive management, (e) shared learning, and (f) continuous improvement to promote integrated energy governance and material flows in cities. Polycentricity can result from advanced planning or selforganization. For instance, while polycentric cities like Singapore (Field 1999) and Shanghai (Ziegler 2006) emerged from an advanced strategic planning, the urban development around the greater Jakarta area is a result of gradual alignments and modifications in planning to explore the potential of interactive technologies and systems, toward the polycentric objective (Hudalah and Firman 2012). Conversely, Shenzhen and Guangzhou are a product of special urban policy (Wu 1998), while London, Amsterdam, Paris, Frankfurt, and many European cities are a product of both self-development and planning (Hall and Pain 2006).

\section{Climate Change and Urban Energy Infrastructure}

"How does a lively neighborhood [city] evolve out of a disconnected association of shopkeepers, bartenders and real estate developers? How does a media event take on a life of its own? How will new software programs create an intelligent worldwide web?," Steven Johnson writes in Emergence (Johnson 2001). According to Mumford (1938), the city is "a point of maximum concentration for the power and culture of a community." Cities are shaped by policies, regulations, and formal written development plans as well as spontaneous, unpredictable self-organizing individual elements that give rise to intelligent and sophisticated systems working on their own prescribed logic. Consider control processes such as traffic lights and their control coordination mechanisms, or the socioeconomic characteristics and attributes of heating and cooling in buildings which influence household energy consumption, or even waste collection and management processes, every city model falls somewhere along a continuum. These self-organization phenomena involve large-scale systems where no single activity or individual exerts control over the processes. It also provides a fruitful source of inspiration for understanding the elements of smart networked cities: how they emerge, deliver societal functions such as personal mobility, and implement niche technological innovations such as piped water infrastructure, heated buildings, pedestrian streetscape facilities, as well as cultural, political, economic and behavioural changes, in a manner often known as "combinatorial innovation" - the ability to combine novel technologies together to create a new wave of discoveries (Youn et al. 2015). (Combinatorial innovation process exhibits two key characteristics: "exploitation" (i.e., continuous refinements of existing combinations of technologies) and "exploration" (i.e., the development of new technological combinations) (Youn et al. 2015).) Today, the narrative of the low-carbon transition puzzle in cities, the ascent of energy-related infrastructure challenges in metropolis, the demands for quality livability standards, and the entire unfolding urban sensibility is fundamentally intertwined with climate change. It is 
also embedded in politics, urban policy, and polycentric governance efforts. The rapid spread of the COVID-19 pandemic is a grim reminder of how global natural disasters exacerbated by unsustainable resource and energy use practices like climate change respect no boundaries.

\section{The Nature of the Challenge}

Dynamism is an abiding feature of smart cities. The dynamic nature of cities is characterized by rising quest for accumulation, of creative destruction and of growth and dislocation spurred on by technological advances which have become symbolic with rapid urbanization and the ascent of megacities. However, climate change now threatens this dynamism and its configurations of urban sensibility and urban resilience. Often characterized as a "super wicked" problem, meaning that its impacts are global, complex, and urgent, climate change is, in part, "driven by policies and technologies that created a path-dependent reliance on high carbon fossil fuels" paradigm, implying that a robust climate solution for governing smart cities should nurture "countervailing policies that trigger path-dependent low-carbon trajectories" (Levin et al. 2012). The impacts of current and anticipated climate change on urban systems are substantial, disrupting energy provision, food distribution, water supply, waste removal, financial markets, and increased susceptibility to pandemics (Agbemabiese et al. 2018). For instance, solar photovoltaic (PV) cells generally work optimally at low temperatures. Climate-induced temperature increase affects the conversion efficiency of a PV cell (Emodi et al. 2019). Increased intensity and frequency of storms disrupt wind power generation, with higher waves lessening electricity production of offshore wind turbines (de Jong et al. 2019). Offshore oil and natural gas facilities and low-lying coastal infrastructure in port cities are equally vulnerable to climate-induced impacts as sea levels rise and wind storms increase in severity and frequency (de Jong et al. 2019; Emodi et al. 2019; Cortekar and Groth 2015). As urbanization spreads up, high unemployment and social unrests in cities, rising competition for resources such as water and food, widening inequality gap, and environmental degradation also threaten urban development. Climate change exacerbates these threats, forcing city authorities to explore explicit sociotechnical interventions to mitigate these threats as well as support economic growth and sustainable low-carbon development.

Attention must thus be broadened toward interactions between climate, energy, and other socio-technical systems. Aging urban infrastructure increases severity of climate risks. Storm-related power outages and direct physical damages from climate-induced natural disasters increase operations and maintenance costs as well as capital investment in energy infrastructure (Markolf et al. 2019; Miller and Hutchins 2017). Furthermore, increased frequency and duration of extreme weather and storm-related power outages result in prohibitively expensive insurance premiums for cities and utilities. A case in point is California's PG\&E bankruptcy filing in 2019, citing billions of dollars in liabilities stemming from wildfires in 2017 and 2018 (Blunt and Gold 2019). Due to these geophysical and climatic disasters, cities 
are increasingly exploring a host of adaptation and mitigation strategies, especially adaptive smart policies, energy frameworks, user practices, programs, and technical solutions to actively phase out existing technologies and systems that lock in institutional and behavioral systems for decades (U.S. Department of Energy 2015). Table 1 summarizes direct physical impacts from extreme events on urban infrastructure systems and potential smart grid solutions.

\section{Smart Grid and the Future of Smart Cities}

Given the centrality of technological innovations in supporting polycentric energy governance efforts related to climate change, water and wastewater management, mobility, economic competitiveness, and a range of other material flows, it is not surprising that cities are expending considerable capital in developing evolutionary business models for explaining innovation, consumer acceptance, and multi-level energy frameworks to better understand socio-technical regimes of transitions and the momentum for renewable energy innovations such as solar PV, wind, and bio-energy. In recent times, cities such as New York City, London, Shanghai, Philadelphia, San Francisco, and Tokyo have adopted smart energy roadmaps, including energy storage, demand response, and smart measurement and reporting, to accelerate their transformation toward clean energy economies. Besides climate-related concerns, energy systems are experiencing several challenges, including lagging investments, energy efficiency gap, diversification of energy generation assets, optimal deployment of expensive assets, and demandside management. Yet, majority of the urban electricity infrastructure is outmoded, stressed, aging, and incapable of responding to these critical issues (ASCE 2017; U. S. Department of Energy 2015; Fox-Penner 2010). In addition, the existing grid is unidirectional and hierarchical and consists of mostly centralized generation assets, meaning it converts only half of the fuel input into electricity without recovering the waste (heat). In this framework, transitioning to a smart grid system addresses this major shortcoming of the power grid, as well as optimizes energy asset utilization and operation efficiency while facilitating roll out of new energy products, services, and platforms. A smart grid is an "intelligent" electrical grid - uses digital, multidirectional communications; provides multiple customer choices to improve reliability of electricity supply, system operating efficiency, and energy services; and consists of mostly distributed generation assets which reduce operating costs while maintaining power grid flexibility and use of pricing models applications.

The unfolding New York energy transition, for example, involved diversifying energy generation mix, through solar PV, wind and bioenergy technologies. The goal is to improve electricity choices for customers as well as enhance the resiliency and flexibility of the electricity, transportation, heating, and industrial systems against possible direct impacts from climate risks. Nyangon and Byrne (2018) used a combination of business model innovation, simulation, and Gary Hamel's business concept innovation framework to study the ongoing reorganization of the New York energy market under the Reforming the Energy Vision (REV) process. Expanding on 


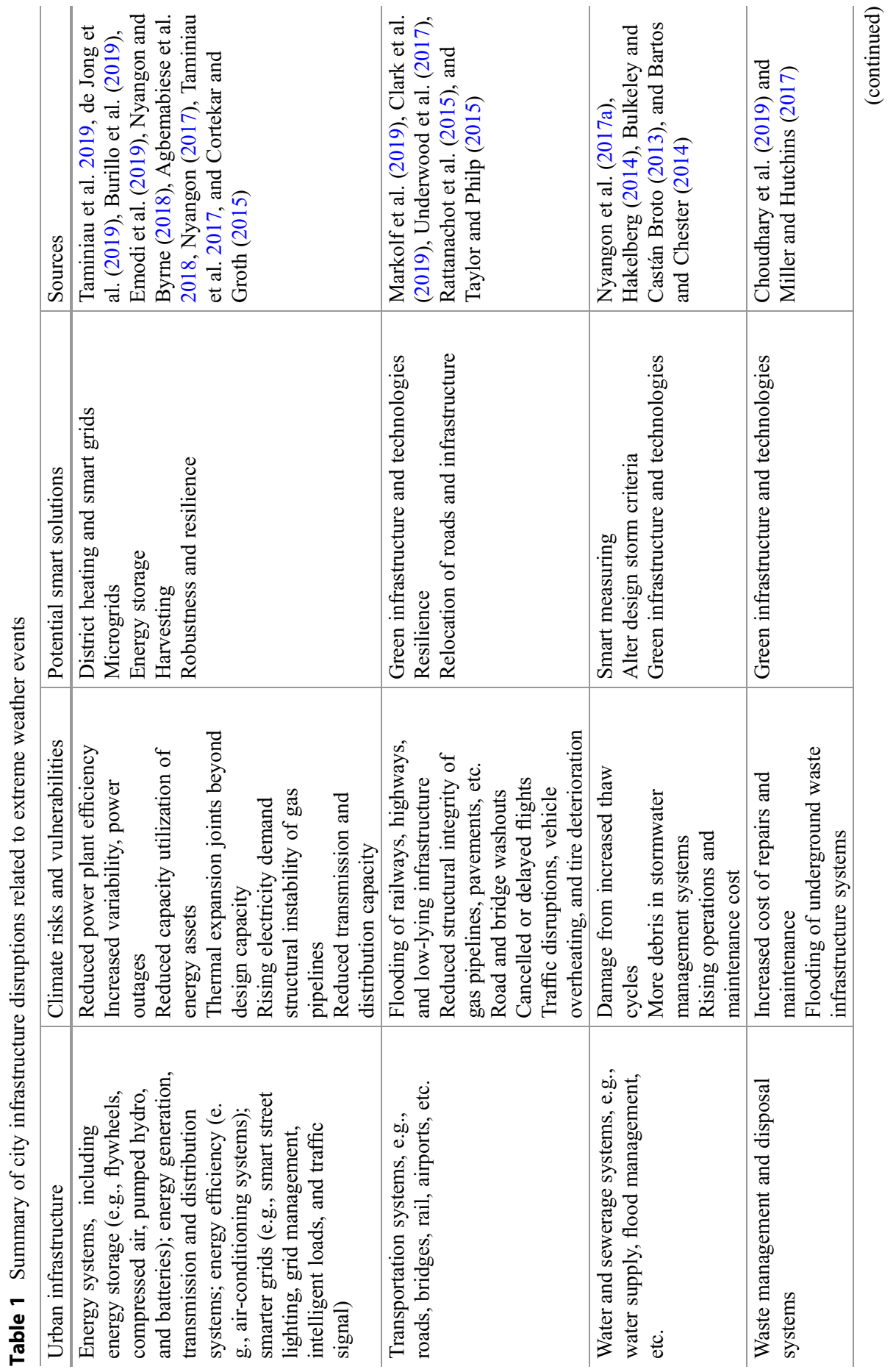




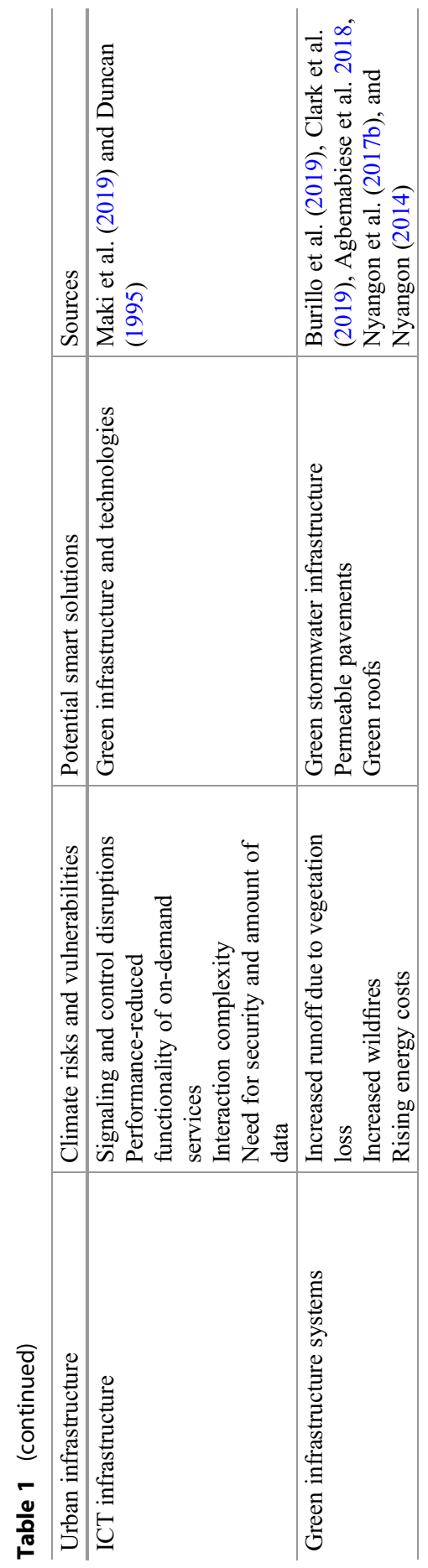


these concepts of diversified power generation mix and intelligent grid infrastructure solutions (DeRolph et al. 2019), this chapter proposes that incorporating elements of smart energy business models such as strategic resource management, revenue model, customer interface, and value propositions, in addition to flexibility and agility, may help animate high levels of reliability and resiliency of urban infrastructure systems, as illustrated in Fig. 1. Furthermore, as the existing urban energy infrastructure continues to age, a new window of opportunity for smart grid applications is emerging. Elements of this smart grid regime include technologies and strategies such as distributed energy resources, energy storage, microgrids, demand management technologies, smart measuring, harvesting, green technologies, and resilience (or robustness).

Most cities in the developed world are already implementing a variation of these smart grid systems, through an assortment of technological innovations, principally by incorporating new technologies and assets into old operations and existing infrastructure. First, at its core, the smart grid implementation is a lateral integration and careful overhaul of the existing grid through information technology, circuit infrastructure, and communication applications. However, because of the electric power sector's tangled economic and regulatory structure, the implementation of smart grid in cities may take the form of "part destination" and "part vision" (U.S. Department of Energy 2015). As such, evolution of the smart grids will be dependent on several factors, notably innovation in technology, energy investment and market structures, policy, regulatory jurisdictions, and a city's needs and requirements. Second, the rising demand for a decarbonized, distributed, and digitalized electricity landscape creates technical and business process challenges for power operators. These challenges include transitioning to a smart grid future, at the highest possible return on investments, as soon as possible, at the minimum cost, without endangering critical energy services in their jurisdictions. Utilities in the developing world have fewer legacy systems and have a clear advantage over their counterparts in the developed world (Farhangi 2010). This is because most cities in developing counties have minimal requirements for backward compactivity with their existing systems, and moving forward investment can be directed toward cleaner, sustainable energy alternatives. Furthermore, cities in the developed world make smart grid investments in a highly regulated environment compared to their counterparts in developing countries. As Fig. 2 demonstrates, a typical smart grid pyramid consists of several technologies, with asset management occupying the base of smart grid development.

Decomposing smart energy systems into implementation components such as energy efficiency, demand-side management programs, energy storage, and microgrids provides cost-effective solution to mitigation and adaptation (Pallonetto et al. 2019; Oprea et al. 2018). Accomplishing each task requires deployment and integration of various technologies to climate-proof the electric grid. Which style of smart grid innovation is right for smart cities? Implementing the smart grid vision involves weaving an array of technologies into the city infrastructure, including predictive analytics, the Internet of Things, big data, and artificial intelligence. In terms of specific projects, examples of smart grid milestones include advanced metering infrastructure (AMI), advanced distribution operations (ADO), advanced 


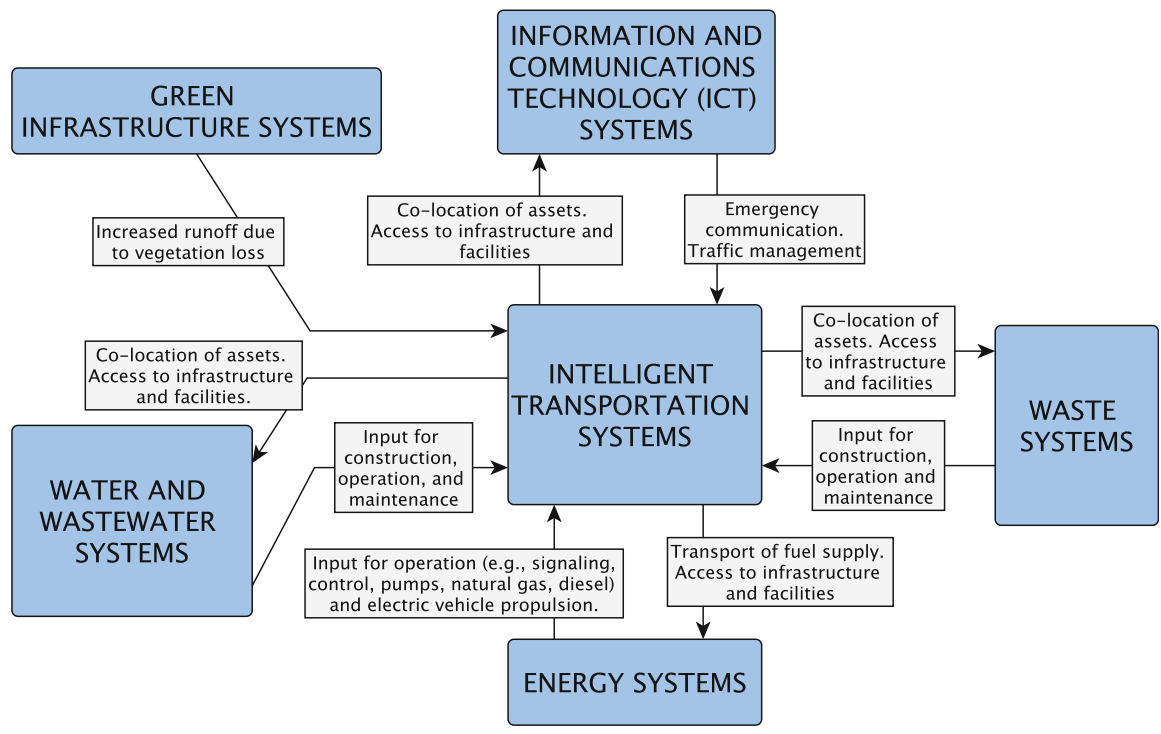

Fig. 1 Common interconnections of critical urban infrastructure systems. (Source: Author's illustration)

transmission operations (ATO), and advanced asset management (AAM). The IBM Smarter Cities Challenge program, for example, promotes a systematic data collection approach and strengthens sustainability planning and urban governance (Alizadeh 2017). AMI comprises of smart meters, communications networks, and information management systems for processing vast amounts of new data. AMI networks enable utilities to collect meter data remotely, facilitate customer participation in demand response and energy-efficiency improvement, and support the evolution of tools and grid management technology that will drive the smart grid future, including outage restoration and integration of electric vehicles and distributed generation. Furthermore, AMI supports practical application of time-varying rates, resulting in peak demand reduction in household energy consumption, in certain cities, by almost $30 \%$ (Wang et al. 2019). While smart meters offer substantial benefits to utilities and consumers, new challenges are being upended such as the need for continuous improvement of interoperability and embedding of AMI architecture systems to address cybersecurity and privacy concerns (Lightner and Widergren 2010). In light of this, the AMI smart grid electricity infrastructure should be scalable, be capable of adapting to changes, and include open-standard technology architecture to enable interoperability among several applications in order to support a wide array of city operations.

For distribution networks, implementing ADO, particularly distribution management system; automated fault detection, isolation, and restoration (FDIR); and distribution automation technologies - i.e., energy management system (EMS), supervisory control and data acquisition (SCADA), distribution management system 


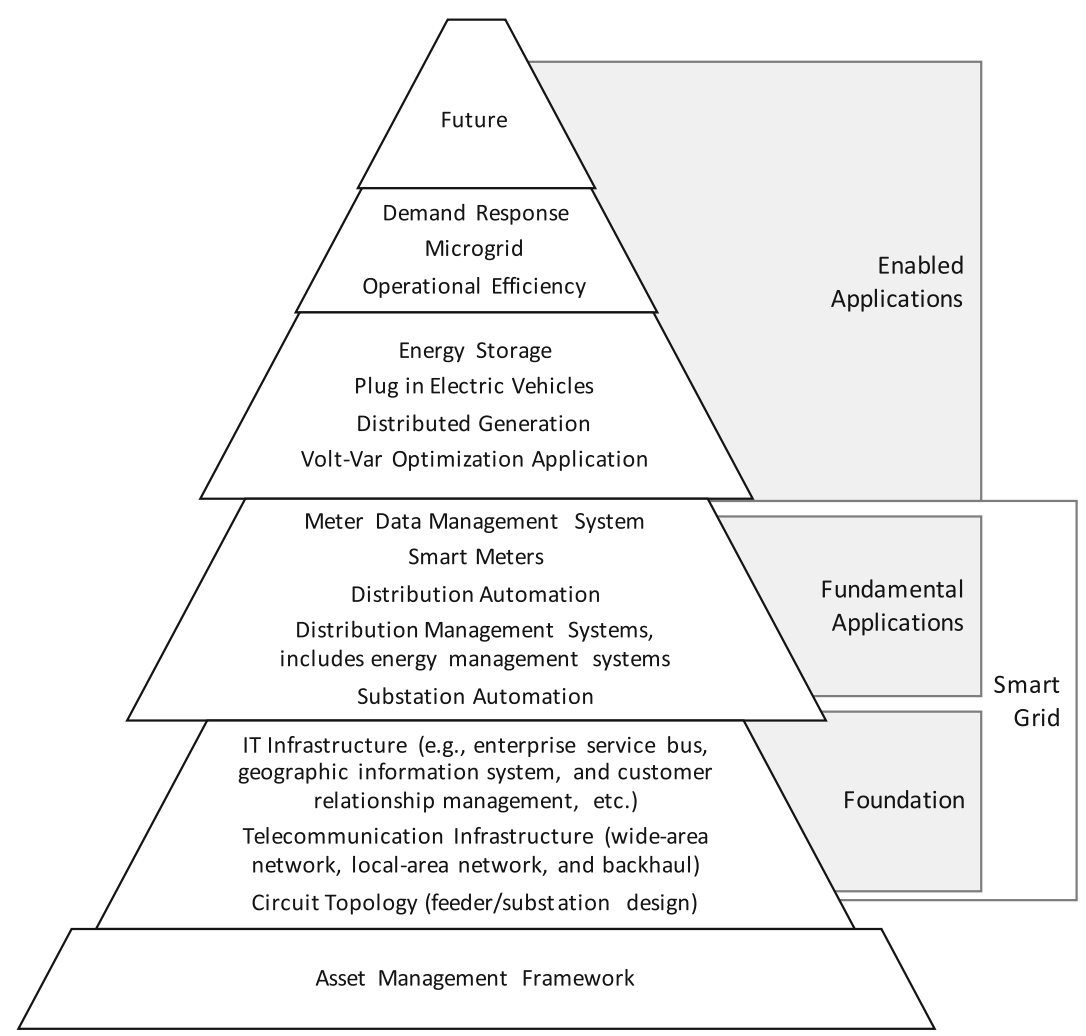

Fig. 2 Components of smart grid pyramid. (Source: Author's illustration)

(DMS), and outage management system (OMS) - could provide increased granularity of and access to smart control mechanisms needed for an adaptive and "selfhealing" distributed grid, improving reliability and climate resilience (Pérez-Arriaga and Knittel 2016). On the other hand, ATO improves transmission reliability and congestion management on the transmission system by integrating the distribution system with regional transmission organizations (RTO) and market applications. Finally, AAM improves the utilization of transmission and distribution assets at the operational level and supports effective management of these assets from a life cycle perspective. AAM includes equipment health monitors and synchrophasor systems consisting of phasor measurement units, communications networks, and data visualization systems. On the grid network, a key distinction is that whereas transmission and consumption are essentially passive elements of the power grid, generation is dynamic.

For cities, identifying and addressing decarbonization, decentralization, and digitalization challenges, require investment in a smart grid to facilitate systematic deployment of energy assets from the outset. Furthermore, characterizing the deployment challenges to establish if they are technological, behavioral, or structural 
provides a good starting point. In addition, integrated assessments, foresight, and scenario facilitate imagination of urban innovation futures, including diversified generation assets, economic transformation, and policy innovation. Therefore, the sequence of knitting in smart energy solutions might vary significantly across cities and regions, and utilities should approach this transition based on a holistic assessment of their assets and the existing regulatory environment. For instance, to advance decentralized energy governance approach, cities such as Songdo and Masdar have adopted a sequence that follows the following strategy to improve resilience and robustness: implement AMI to establish physical communication infrastructure to the energy generation assets, followed by ADO to assure selfhealing of the distribution system, and then ATO systems to address congestion concerns on the transmission system. Finally, implement AAM to support "smart" real-time transactions, with predictive asset-modeling capabilities built on real-time data (Lee et al. 2016).

As James et al. (2020) highlight in the introduction chapter, climate change adaptation measures, including distributed energy resources, provide double dividend benefits such as emission reduction, energy savings, and operational improvement. In broader terms this enables cities to improve their energy security, grid reliability, and demand-side management. To realize this goal, technology, market, and policy-oriented strategies for smart grid such as energy storage, microgrids, demand response, and distributed energy resources are discussed to explain their role in optimizing existing energy assets and mitigate climatic extremes. In addition, the modernization of the electric power grid policy framework is increasingly not an optional add-on for utilities but an essential planning component of urban energy infrastructure.

\section{Emerging Models for Urban Energy Transformation}

This section discusses some of the components and elements of a smart grid in Fig. 2.

\section{Distributed Energy Resources}

Distributed energy resources (DERs) enable active participation by consumers in the power grid. DERs include PVs, small wind power plants, small natural gas-fired generation and combined heat and power (CHP) technologies, energy efficiency, electricity and thermal storage, demand response (DR), heat pumps, and electric vehicles (EVs). (While wind power systems are often connected at distribution voltages, they are a mature technology and rarely deployed at customer sites.) All of these technologies have unique characteristics and sometimes complex interactions with the distribution grid. For example, while rooftop and ground-mounted solar PVs and wind power systems are fueled by non-dispatchable sources of energy and therefore have variable energy output, electricity and thermal storage and fuel 
cells provide more flexibility and reliability to the grid (Nyangon 2017). On the other hand, energy efficiency, DR, EVs, and heat pumps are customer dependent and therefore behavior- or participation-centric. In this regard, city planners could assess the potential of the DERs from two main perspectives: accommodating DERs, which implies that their implementation may create adverse impacts on the electric distribution network, and integrating DERs, which means that they may mitigate grid constraints such as limited hosting capacity and unbalanced power flow (Trencher and van der Heijden 2019; Eid et al. 2016).

The transformation from consumers to prosumers - active energy market participants who consume less bulk kilowatt-hours from the grid due to energyefficiency improvements while producing more through small-scale distributed generation - is one of the most exciting research areas of DERs and grid service development. (The term prosumer refers to energy consumers who are also producers.) For urban areas where conventional CHP plants are available, DER installations can be used to improve power systems restoration after power outages, improve frequency stability, and reduce blackouts. DER electricity development in cities, particularly solar PV and wind power systems, can be traced to favorable support policies and incentives by national and local governments, private sector financial investments, and technology and market improvement (Nyangon et al. 2017b). DER can help cities lower and stabilize household electricity costs, which are passed down to consumers, and improve grid flexibility because they are far more flexible to site and operate than fossil-based technologies. At the transmission level, flexible alternating current transmission system (FACTS), phasor measurement unit (PMU), fault current limiters, and synchronous switching devices provide instantaneous voltage support during extreme weather events and storms (FoxPenner 2010). In addition, they also enhance power quality, balance reactive power, and improve reliability and efficiency of bulk power shipment over long distances during power outages. At the distribution level, high-speed transfer switches and dynamic volt-amperes reactive (DVAR) support load isolation, improve grid reliability, and minimize power quality events. This makes a combination of DERs and smart grid investment a cost-effective strategy for improving grid flexibility to mitigate against climate-induced impacts.

Furthermore, because DERs accommodate all generation sources particularly intermittent, non-dispatchable renewable energy sources, storage options, and lowcarbon renewable natural gas-fired generation systems as well as cogeneration, they sustain a clean energy economy and urban infrastructure development. DERs also offer cities opportunities to reduce their near- and long-term greenhouse gas emissions through "solar city" strategy and economics (Byrne and Taminiau 2018), thereby mitigating climate impacts by reducing total GHG emissions. DERs perform twin functions: (1) adaptation and (2) mitigation of climate impacts. For example, combined cooling heat and power (CCHP) and cogeneration systems are a form of an integrated DER energy system, which delivers both heat and electricity, as well as improve system efficiency (Prinsloo et al. 2016; Eid et al. 2016). Such DER technologies can be paired with information communication technologies (ICTs) in cities to enable communication and control of the DER resource of interest. 
ICTs can also improve local system signaling and reliability of electrically constrained portions of the grid, thus providing critical system resiliency during widespread outages caused by extreme weather events and other disruptions.

\section{Energy Storage}

Utility-sited energy storage provides the needed integration with variable renewable energy sources to mitigate supply-demand imbalances. Previously, pumped hydropower plants had been the only known grid-integrated technology for delivering significant flexibility to the power grid (Beires et al. 2018). Common electricity and thermal storage technologies include electrochemical or physical (e.g., compressed air) mediums, ice storage, molten salt storage, and others. In recent times, the growth of large- and small-scale battery storage has supported stabilization of power grids in cities. Electromobility is the main technology driver of the growth of battery storage, and as Hoarau and Perez (2019) show solar PVs, lithium-ion batteries, and electric vehicles (EVs) are emerging as the three disruptive innovations in power grids. Lithium-ion battery technology has very good power and energy density at high frequency and robustness which makes it suitable for consumer electronic devices (Nykvist et al. 2019).

Another new factor is that advances in smart grid technologies make deployment of energy storage to integrate high amounts of renewable electricity systems possible. This necessitates maximizing locational value of DERs to deliver reliability services in locations where networks are frequently constrained (Burger et al. 2019). To minimize network supply-demand imbalances and integrate a growing share of variable power into the grid, investment in distribution network assets is necessary. Additionally, to improve electric grid resilience in cities, on-site renewable energy systems can be combined with energy storage (i.e., batteries, ultracapacitors, and flywheel energy storage), as well as other auxiliary equipment and services. When paired with energy storage, and facilitated by smart grids, these systems provide a reliable backup power in the event of a blackout, as well as ultra-clean power needed for sensitive industrial processes.

Apart from batteries, utilities can deploy vehicle-to-grid (V2G) distributed storage devices to support grid balancing and enhance peak-shaving capability in cities. Noel et al. (2019) analyzed willingness-to-pay attributes for EVs in Norway, Iceland, Denmark, Sweden, and Finland and found that V2G capability is significantly positive. With $\mathrm{V} 2 \mathrm{G}$ and smart grids, municipal utilities can flatten their daily consumption load curves, optimize grid management, and improve system flexibility (Pérez-Arriaga and Knittel 2016) with significant benefits to the environment, urban air quality, energy security, and ecological integrity. 


\section{Microgrids}

Microgrids are self-contained, self-sustaining grids, operating in a small geographical region, often powered by DERs, and can operate in both grid-tied and islanded modes (Hussain et al. 2019; Farzan et al. 2013). They are a potential solution to climate-induced power disruption events due to their islanding ability. Urban infrastructure such as hospitals, schools and universities, data centers, and municipal facilities and offices are examples of facilities that require unusually high levels of reliable electricity and can benefit from microgrid deployment, operating either as a stand-alone system or in conjunction with the municipal utility system, to guarantee proactive scheduling, feasible islanding, and outage management and reduce the impact of major disruptions. A notable microgrid project in the United States is a Hurricane Sandy star, the Princeton University campus. The Princeton microgrid consists of 15 MW CHP plant, a 5 MW PV array, and a load prioritization strategy during islanding. (Two years after Hurricane Sandy, recognition of Princeton's microgrid still surges https:/www.princeton.edu/news/2014/10/23/two-years-afterhurricane-sandy-recognition-princetons-microgrid-still-surges) Microgrids provide reliable onsite power supply with fewer outages, and self-healing power systems, through the use of digital information, automated control, and autonomous systems (Farzan et al. 2013). By enabling integration of multiple DERs with advanced controls and communication platforms, Washom et al. (2013) explain that microgrids offer significant system operational benefits and ameliorate constraints associated with the centralized electric grid.

\section{Demand Response and Energy Management Systems}

Adaptation measures in the power sector, to implement climate change resilience, are best done at supra-local level by county and regional governments, because of their broad legislative powers. Near-term demand management measures (e.g., smart meters, new tariffs, and intelligent load management) provide cost-effective mitigation strategies as well as enhance flexibility and grid management solutions for reducing carbon intensity in the electricity sector. In this regard, demand management and demand response offer two strategies to even outpeak power demand: (1) load shedding and (2) load shifting. According to the Federal Energy Regulatory Commission (FERC), demand response refers to "changes in electric usage by demand-side resources from their normal consumption patterns in response to changes in the price of electricity over time, or to incentive payments designed to induce lower electricity use at times of high wholesale market prices or when system reliability is jeopardized." (Federal Energy Regulatory Commission. Reports on demand response and advanced metering http://www.ferc.gov/industries/electric/ indus-act/demand-response/dem-res-adv-metering.asp) Demand response is a subset of end-use customer energy solutions known as demand-side management (DSM). Besides demand response, DSM includes energy efficiency programs. Various entities including transmission and distribution system operators, utility companies, 
and end-use consumers can all benefit from demand response, either in the form of price-driven or incentive-based demand response programs.

Load shifting tries to smooth the power demand away from peak periods through price incentives thereby improving power efficiency and optimizing resource allocation to achieve efficient electricity use (Kuiken and Más 2019; Varma and Sushil 2019; Wang et al. 2018). Load shedding, on the other hand, is a form of targeted blackout where utilities enter into agreement with large electricity consumers such as industries or universities to reduce their consumption during peaking crises in return for discounted rates. This is a form of incentive-based demand response program and is triggered either by high electricity prices or a grid reliability problem. Dynamic pricing can dramatically reduce energy demand swings and increase overall generating efficiency. Demand response as a proactive measure can be implemented both manually and automatically. When fully automated, human intervention is removed and demand response is initiated at a home, building, or facility through receipt of an external communications signal that shifts the load, thus reducing peak and total energy demand (Fox-Penner 2010). The manual demand response entails controlling the use of certain appliances, for example, dishwashing machines, in different time periods of the same day. Semi-automated demand response, on the other hand, involves some form of human intervention whereby a pre-programmed demand response strategy is initiated through a centralized control system.

The success of dynamic pricing methods nevertheless depends on consumer behavior. The current price-driven demand response programs include time-of-use (TOU) pricing, critical peak pricing (CPP), and real-time pricing (Yan et al. 2018; Faruqui and Leyshon 2017). Besides dynamic pricing, cities are engaging investorowned utilities (IOUs) in their territories to implement smart building automation and control solutions to improve provision of energy services. Advanced metering, time-varying rates, dynamic market-based prices, and energy management systems (EMSs) have the potential to reduce uncertainty in electricity prices than ever before. Without these smart controls, the problems of the grid will worsen, and critical operations in cities will be severely affected. Siemens has observed that investments in smart grids - resulting in increased usage of load shedding and load shifting could reduce national electricity needs by nearly 10\%. (Smart infrastructure business update: https://assets.new.siemens.com/siemens/assets/public.1557934458.69c056d92369-49ddba5e-1a519a71049e.dgcustomersummit2019.pdf)

\section{Smart Measuring Systems}

Significant progress has been made in improving measurement, reporting and verification (MR\&V) system for urban energy as well as other performances like air, environment, water, waste management, transport and mobility. However, the indicators used for measuring these performances and smartness rarely consider a holistic approach that goes beyond one component (economy, environment, mobility, people, governance). Additionally, a lack of standardized common metrics for $\mathrm{MR} \& \mathrm{~V}$ adds complexity in governance and information management. Under these 
circumstances, energy performance measurement through data-driven powered insights and peer-city benchmarking strategies have emerged as viable solutions for improving the understanding of the complexity and dynamism of urban energy transition - from fossil fuels to renewable power (Hiremath et al. 2013). As far as the building energy dimension is concerned, polycentric frameworks based upon people-centric and smart measuring strategies, particularly common indicator approaches, could be deployed to improve both the measurement of energy supply and demand metrics in cities. In this framework, these efforts could focus on the linkages between multiple innovations and sociotechnical systems like integrated district heating systems in which electricity grids are coupled with gas networks, rooftop solar PV systems for electricifying residential buildings, V2G configurations, integrated urban planning and transport systems via TOD, and intermodal transport to facilitate efficiency of transport links, nodes, and the provision of services within and across cities (Pires et al. 2014).

By adopting a common indicators approach, cities can also improve reporting of energy project performance on an ongoing basis. Smart, automated performance measurement and control opportunities will arise in many ways:

- Intelligent monitoring and control of energy-consuming devices to reduce performance variations, engage energy users in new decisions and action that reduce energy, and improve energy savings guarantee.

- Foster better understanding of the drivers of energy-efficiency improvement and changes in the social, natural, and built environments.

- Use targeted incentives and rewards to increase participation and commitment to energy efficiency actions.

- Any governmental program providing a subsidy for clean energy projects can require reporting as a condition.

- Leverage technology to promote smart metering of generation resources, transportation system efficiency, appliance labeling, building codes, and energy savings performance contracts (ESPCs).

Standardization of ICT interfaces for smart cities will also support the New Urban Agenda (Habitat 2019) and a specifically Urban Sustainable Development Goal (USDG) as part of the United Nations 2030 Agenda for Sustainable Development, encourage continuous learning and improvement, promote accountability, and identify performance gaps (d'Alençon et al. 2018). Under a common framework of $M R \& V$, learning, cooperation, and emulation among different cities with common smart city objectives and characteristics can be enhanced to promote smart mobility, smart urban infrastructure, smart economy, smart energy, and smart urban governance. An example of a comprehensive framework for measuring economic, environmental, and social performance of cities is the release of the Sustainability Tools for Assessing and Rating (STAR). The STAR framework offers a menu-based system for enabling cities to build inclusive, equitable, and accountable development (STAR Communities 2017). It is a leading framework for assessing and promoting sustainability performance of cities at different scales. With the STAR framework, 
cities can evaluate their performance across different goal areas covering the built environment and climate and energy (STAR Communities 2015), discover "best practices" that move the needle toward the identified outcomes, and communicate their progress to the stakeholders.

However, cities and their measurement metrics are network phenomena and cannot be studied in isolation. If the measurement indicators fail to improve or fully capture the resource and material flows in cities, the performance evaluation of the city's assets could be considered incomplete or undervalued (Pires et al. 2014). In addition, without fully understanding the energy and material flows, systematic evaluation of the measurement indicators could be problematic thus undermining long-term planning and development goals. To address these concerns, a smart measurement framework should incorporate three main guiding principles: bottom-up stakeholder-driven approach, consensus-based process, and inclusivity. Stakeholder-driven process fosters synergy among different city agencies and entities, thereby improving decision-making process. Consensus-based process promotes transparency and accountability, offering immense opportunity for deeper engagement on smart development. Stakeholder-driven and consensus-based approaches together foster improved qualitative assessment of urban complexity and dynamics. On the other hand, inclusivity refers to the balance between rigor and comprehensiveness of the measurement metrics in order to address the full range of measurement, reporting, and verification systems.

\section{Harvesting}

Rapid urbanization, population growth, climate change, and high cost of maintenance of urban infrastructure projects have pushed city planners, engineers, and scientists to look for alternative and sustainable methods of harvesting energy such as solar, wind, hydropower, and geothermal. Solar PV panels absorb sunlight as a source of energy to generate electricity in the form of direct current (DC). Solar cells are made of semiconductors, such as wafer-based crystalline silicon cells or thin-film silicon cells. Solar energy harvesting occurs when electrons in the PV cells are freed upon after being struck and ionized by photons from the sun to power electrical devices.

Examples of harvesting include the following projects:

- Solar and wind energy: harvesting both bulk and distributed solar and wind power, from sparsely populated regions with low electrical demand outside the city and transmitting it to urban areas where electricity is needed.

- Biofuel or bioenergy: sustainably harvesting bioenergy from crop residues, crops, wood, or wood waste using methods that do not contribute to emissions.

- Stormwater mitigation: promoting green infrastructure such as green roofs and urban rainwater harvesting for use in landscape irrigation or interior building applications, which would reduce water consumption. Rainwater harvesting also saves energy incurred in municipal networks for transportation and distribution. 


\section{Green Technologies}

Despite documented compelling benefits of green technologies - e.g., addresses climate change adaptation and mitigation, sustains economic growth and investment, improves energy utilization efficiency, and promotes substitution of fossil fuels with clean energy in production - pragmatic investments in these technology solutions remain limited, uncoordinated, and ineffectual relative to demand and the climate challenge (Weina et al. 2016). A review of heterogeneous effects of green technology innovations across cities with different income levels shows that these investments can stimulate total-factor carbon productivity as well as human capital (Du and Li 2019) in several ways. First, the applications of green technology innovations improve climate change adaptation and mitigation, thereby promoting health and well-being of existing residents. Second, green technologies advance energy innovations and utilization efficiency. Third, green technology innovations can promote the substitution of fossil fuels with low-carbon energy in production, supporting industry upgrade which in turn spurs economic growth. However, in practice, investments in green technology applications face barriers such as financing obstacles as well as market and institutional complexities. This is compounded by uncertainty and risks associated with new green technologies - smart street lighting, lithium-ion batteries for EVs, solar PVs, offshore wind power, biofuels and bioethanol, and cost-effective green vehicles - with respect to regulatory structure, financing barriers, and systemic institutional gaps (Kanger et al. 2019; Nykvist and Nilsson 2015; Lam et al. 2010). Unfortunately, this affects the diffusion of these technologies in cities. Second, difficulties in administering huge capital investments due to legal and administrative challenges, complex investment instruments, and lack of specialized expertise restrict the level of infrastructure-scale investments at the city-level because of higher initial cost.

A key element of green technology innovations is that most investment decisions target a specific sector (e.g., energy, utilities, manufacturing, etc.), a specific asset class (e.g., fixed income, equities, infrastructure, etc.), or a specific city (e.g., cities in the developed world or the developing world). While there is significant investment potential in many of these areas - particularly in renewable energy, energy efficiency, and decarbonization technology - the growing investment gaps and the tightening of capital in the global banking sector mean that investors often weigh investment decisions against risk profiles of a city, and not merely on the merits of the green technology innovations alone. To generate new sources of revenues to fund green technologies, cities should expand the share of green financing, issue municipal-backed "green bonds" to promote socially responsible investments, pursue new international sources of climate funding, reduce taxes on green products, and promote new cooperation on green technologies with other cities through forums such as C40 Cities, Global Covenant of Mayors, Cities Alliance, and ICLEI - Local Governments for Sustainability. Table 2 summarizes risk factors focusing on the green technology aspects of a smart city programs. 


\section{From Robustness to Resilience}

Robustness and resilience are two complementary concepts applied in various energy studies, including energy security assessment (Martišauskas et al. 2018), building energy design and retrofits (Ascione et al. 2017), grading building energy performance (e.g., energy use intensity, total energy, peak power) (Papadopoulos and Kontokosta 2019), and energy installation (e.g., heating source, ventilation system, status of refurbishment) (Pasichnyi et al. 2019), to deal with the increasing uncertainties and meta-complexities that characterize energy systems in cities. Resilience refers to the ability of a system to "rebound" or withstand initial shock (interruptions) (Hughes 2015), while robustness is the capacity to maintain functions of a system (policy, political system, organization, or institution) in spite of uncertainty (Capano and Woo 2017). The nonlinearity and spillover effects associated with the complexity of climate hazards, urbanization, and unforeseen population and demographic shifts, combined with widespread and systemic environmental damage, aging infrastructure, pollution, and mounting health costs in cities, require a degree of flexibility in policy and governance systems. Indeed, it necessitates combinatorial innovations in technological exploitation and exploration (Youn et al. 2015). These adaptations also demand application of a resilience-based approach rather than robustness per se to address these complex, emergent, and evolving threats to urban energy systems (Nyangon et al. 2017b). Is robustness synonymous with resilience? How can cities advance flexibility, agility, and overall resilience to address technological and institutional "lock-in" effect inherent in our urban infrastructure systems? These are vital questions for city authorities and can be resolved by implementing incremental adaptations in public policy and policy design to mitigate potential risk of system lock-in effects for new technological solutions and corresponding institutional path dependency that can prevent these transitions from taking place.

In addition to robustness, cities can address uncertainties and complexities of energy networks by integrating complex adaptive systems, dynamic planning, flexibility, and agility in order to advance greater resilience. As a result, contemporary urban studies are increasingly emphasizing resilience of the socioeconomic and built environment and technical functions of cities by including these additional elements in urban policy formulation in order to strengthen and fortify city assets in the face of increased risk of failure. As Spaans and Waterhout (2017) explain, "resilience includes not only the shocks (such as earthquakes, fires, and floods), but also the stresses that weaken the fabric of a city on a day-to-day or cyclical basis. By addressing both these shocks and stresses, a city becomes more responsive to adverse events, and is overall better equipped to deliver its functions in both good times and bad, to all populations." Similarly, Davoudi (2012) explains that "resilience is defined not just according to how long it takes for the system to bounce back after a shock, but also how much disturbance it can take and remain within critical thresholds." Notable methods for improving resilience in energy governance include diversifying energy supply (e.g., solar PV, wind, biomass, if available + fossil especially gas-fired generation and CHP) (Nyangon and Byrne 2018) and improving 
Table 2 Risk factors associated with smart city solutions

\begin{tabular}{|c|c|c|c|}
\hline Risk-tier & Risk events & Mitigation strategy & Risk taker \\
\hline Technical risk & $\begin{array}{l}\text { Performance of } \\
\text { technology, technical } \\
\text { availability, technical } \\
\text { lifetime, equipment } \\
\text { defect/degradation, grid } \\
\text { connection failure, } \\
\text { inability to fulfil } \\
\text { warranties and } \\
\text { guarantees, } \\
\text { technological change, } \\
\text { etc. }\end{array}$ & $\begin{array}{l}\text { Proven technology } \\
\text { Quality components } \\
\text { correctly dimensioned } \\
\text { Manufacturer } \\
\text { warranties and } \\
\text { performance } \\
\text { guarantees } \\
\text { O\&M guarantees } \\
\text { Take-and-pay power } \\
\text { purchase agreements } \\
\text { (PPA) }\end{array}$ & $\begin{array}{l}\text { Manufacturer, } \\
\text { engineering } \\
\text { procurement, and } \\
\text { construction (EPC) } \\
\text { contractor, O\&M } \\
\text { contractor }\end{array}$ \\
\hline $\begin{array}{l}\text { Energy } \\
\text { resource risk }\end{array}$ & $\begin{array}{l}\text { Variability and quality } \\
\text { of technical potential, e. } \\
\text { g., solar irradiation data, } \\
\text { wind speed data, } \\
\text { simulation model }\end{array}$ & $\begin{array}{l}\text { Use of proven } \\
\text { databases with well- } \\
\text { correlated theoretical } \\
\text { and empirical data } \\
\text { On-site measurements }\end{array}$ & Developer, consultants \\
\hline $\begin{array}{l}\text { Extreme } \\
\text { weather risk }\end{array}$ & $\begin{array}{l}\text { Extreme wind } \\
\text { conditions, heatwaves, } \\
\text { flooding, thawing, and } \\
\text { snowstorm }\end{array}$ & $\begin{array}{l}\text { Use of technical } \\
\text { protection measures } \\
\text { Site selection }\end{array}$ & $\begin{array}{l}\text { Designer, EPC } \\
\text { contractor }\end{array}$ \\
\hline $\begin{array}{l}\text { Construction } \\
\text { risk }\end{array}$ & $\begin{array}{l}\text { Cost overruns, } \\
\text { completion delay, non- } \\
\text { completion, project } \\
\text { quality, abandonment, } \\
\text { force majeure, natural } \\
\text { disasters, political risk, } \\
\text { land availability }\end{array}$ & $\begin{array}{l}\text { Fixed time and budget } \\
\text { turnkey contract } \\
\text { (EPC) completion } \\
\text { guarantees } \\
\text { Monitoring reports } \\
\text { Performance reports } \\
\text { Penalty clauses } \\
\text { Cost contingency } \\
\text { funds }\end{array}$ & $\begin{array}{l}\text { Manufacturer, EPC } \\
\text { contractor, sponsor }\end{array}$ \\
\hline Offtake risk & $\begin{array}{l}\text { Credit risk, large level of } \\
\text { investment/long tenor of } \\
\text { return, additional equity } \\
\text { required later, } \\
\text { commitment, } \\
\text { misalignment of } \\
\text { investors' objectives }\end{array}$ & $\begin{array}{l}\text { Long-term offtake } \\
\text { agreement (PPA) take- } \\
\text { and-pay, credit } \\
\text { enhancement, } \\
\text { accelerated taxes, } \\
\text { regulations, etc. }\end{array}$ & Sponsor, offtaker \\
\hline $\begin{array}{l}\text { Environmental } \\
\text { risks }\end{array}$ & $\begin{array}{l}\text { Risks related to the } \\
\text { location and } \\
\text { surrounding } \\
\text { environment of the } \\
\text { project, impact on local } \\
\text { residents, weather, and } \\
\text { environmental } \\
\text { opposition }\end{array}$ & $\begin{array}{l}\text { Environmental impact } \\
\text { assessment } \\
\text { Risk of incurring fees, } \\
\text { fines, or withdrawal of } \\
\text { license }\end{array}$ & Developer, sponsor \\
\hline
\end{tabular}

socioeconomic metrics through enhanced choices for electricity services for customers and developing cost-efficient mini- and microgrid networks. Such diversity allows smoothing of daily electricity load patterns and shifts electricity load to 
locations with greatest demand, thereby increasing cost-efficiency and network management.

Bisello and Vettorato (2018) offer a seven-part multiple benefits approach as a paradigm for evaluating smart urban energy transition - smart economy, smart governance, smart built environment, smart mobility and connectivity, smart community, smart services, and smart natural environment - and its positive impacts on resilience of energy infrastructures, well-being, health, indoor comfort, property value increase, and competitive advantage on the smart city. Energy is the cornerstone of these components. With the rapid progression of climate change, advances in technological innovation, and urbanization shifts, energy systems, and by extension these components, will likely become more complex and interconnected. As a result, a better understanding of interconnectedness and the resulting indirect vulnerabilities of urban energy systems is necessary to mitigate increasing risks. In doing so, cities ought to advance a nexus thinking and integrated urban design, planning, and management rather than a sectoral line ("silos") approach, meaning municipalities can appropriate synergistic benefits of better integrated resource management.

Finally, recourse to moving beyond robustness (toward resilience) is an essential component of smart city energy networks. In particular, peer-city benchmarking is vital for understanding when robustness is particularly suitable and when it is not based on the complexity of smart cities. Regular peer-to-peer comparison and evaluation of the foundational measurement metrics (e.g., smart growth, environmental integrity, healthy communities, and social inclusion) are desired to gain a better idea of specific actions that can enhance flexibility, agility, responsiveness, and inclusive decision-making. Finally, quantitative and qualitative methods for benchmarking energy strategies and energy protocols toward smart resource use are needed to foster resilient urban energy frameworks for better decision-making in cities.

\section{A Polycentric Approach to Smart City Energy Governance}

The above discussion highlights several key elements of the smart city energy governance: (a) networks (e.g., the existence of networks for facilitating mutual learning processes between cities to deliver quality urban services, promote effective urban governance, and improve management structures); (b) scales (e.g., connecting and aligning several scales, actors, and responsibilities rather than containing efforts to one scale;) (c) polycentric energy systems (e.g., thinking of solutions in context, notably developing numerous smaller, modular rooftop solar PV plants located closer to consumers); and (d) the common pool issues of energy access, rebound effects, energy justice, and inequality for greater acclimatization of the benefits of electricity decarbonization in cities. Polycentricity refers to decentralized governance systems encompassing several independent centers of decision-making often performing function in a coordinated fashion across sectors and scales (Aligica and Tarko 2012; Ostrom 2010). The emerging "polycentricity" paradigm and thinking or 
"adaptive regulatory framework" in smart city governance enables a salient conceptualization of citywide transformations. Notably, governance for transformations, governance of transformations, and transformations in governance (Burch et al. 2019) resulting in significant environmental improvements (such as waste reduction and air-pollution abatement), social progress (e.g., social relations and growth of green jobs), and economic benefits (e.g., reductions of energy costs).

The nonlinearity and complexity of smart grid challenges, especially climate risks, urbanization, demographic shifts, systemic environmental change, and energy infrastructure investment deficit facing many cities, can be addressed by a "polycentric" strategy that incorporates shared learning, adaptive management, civil society strategies, and creative experimentation to support existing transformative innovations and empower local energy development. Initially proposed in the 1960s and 1970s (Aligica and Tarko 2012), polycentric strategy has been applied to evaluate "solar city" economics (Byrne and Taminiau 2018), climate justice (Fischedick et al. 2018; Martinez-Alier et al. 2016; Ostrom 2010), urban energy planning for $100 \%$ renewability in Frankfurt and Munich cities (Radzi 2018), alleviating urban traffic congestion ( $\mathrm{Li}$ et al. 2019), assessing energy efficiency gap (Zou et al. 2019), and evaluating new capacities for transformative climate governance in New York City (the United States) and Rotterdam (the Netherlands) (Hölscher et al. 2019). In terms of smart energy infrastructure governance, polycentric policy underscores the elements summarized in Table 3 - transparency, inclusivity, accountability, and responsive network practices.

Jones and Kammen (2014) posit that urban development and suburbanization have created key questions: what is the degree of change of each urban energy process, for example, in energy cost savings, mitigation of greenhouse gas emissions, and material flows in cities? How are cities reshaped by governance processes as they grow? Polycentricity offers a promising strategy for addressing these questions. It provides a viable strategy to rethink energy infrastructure investments with a view to implementing smart energy systems for residential homes, smart buildings, and increasing energy security through energy analytics and artificial intelligence applications. It also resonates with the concepts of regime complexity (Keohane and Victor 2011), institutional fragmentation (Zelli and Asselt 2013), and experimentalist governance (Jordan et al. 2015), allowing for flexibility, agility, social learning, systems-oriented approach, and changing course when new information becomes available. In essence, a polycentric approach engages multiple stakeholder groups in the design, implementation, and management of smart energy future in cities. As a result, a polycentric system spans across multiple scales. For example, both centralized and decentralized electricity networks serving a city's jurisdiction such as the New York City metropolitan area or London metropolitan belt are a part of city or regional or national grids.

Many smart city developments already exhibit elements of a polycentric governance approach. For example, Ruhr in Germany, Stoke-on-Trent in the United Kingdom, and the San Francisco Bay Area in the United States all have complex coordination arrangements across sectors and scale, involving different stakeholders at multiple levels. Additionally, a number of cities are already implementing 
Table 3 Key elements of polycentric policy

\begin{tabular}{|c|c|}
\hline Elements & Polycentric discourse applications \\
\hline $\begin{array}{l}\text { Stakeholder-driven } \\
\text { approach }\end{array}$ & $\begin{array}{l}\text { Polycentric policy designs emphasize community ties and } \\
\text { collaboration among various agencies and civil societies }\end{array}$ \\
\hline $\begin{array}{l}\text { Enhanced accountability } \\
\text { and legitimacy }\end{array}$ & $\begin{array}{l}\text { Project sponsors of polycentric policy designs support internal and } \\
\text { external transparency and accountability, for instance, in the } \\
\text { planning and management of resources, to cater for the growing } \\
\text { urban complexity and dynamics }\end{array}$ \\
\hline $\begin{array}{l}\text { All-inclusive and more } \\
\text { equitability }\end{array}$ & $\begin{array}{l}\text { Polycentric systems address a full range of environmental, social, } \\
\text { and economic issues as well as involve a diverse number of } \\
\text { stakeholders }\end{array}$ \\
\hline $\begin{array}{l}\text { Adaptive governance } \\
\text { system }\end{array}$ & $\begin{array}{l}\text { "distributes decision-making powers across the system and ensures } \\
\text { coordination through an overarching system of norms and rules } \\
\text { that defines the logic of interactions between actors" (Biesbroek } \\
\text { and Lesnikowski 2018) to encourage polycentric innovation across } \\
\text { scale, place, and time }\end{array}$ \\
\hline Shared learning & $\begin{array}{l}\text { Emphasize creative experimentation, trust building, and problem } \\
\text { resolution }\end{array}$ \\
\hline More robust & $\begin{array}{l}\text { Ability to address grand challenges of governance in megacities } \\
\text { through continuous improvement and steady accumulation of } \\
\text { marginal changes across sectors and scale - if one approach or } \\
\text { domain fails, others can step in, hence, greater resiliency }\end{array}$ \\
\hline
\end{tabular}

decentralized and "smart" infrastructure solutions, including rooftop solar technologies which provide parties with multiple simultaneous roles as both producers and consumers - prosumers of energy. In addition, these plans address unique challenges of the city, for instance, by establishing "smart" solutions that support short- and long-term operational risks, as well as incentives. Cities can formalize these requirements into (smart grid) technical standards in order to institutionalize the polycentric smart energy framework. Together, these plans and strategies, supported by "orchestration" of cooperation involving diverse actors and technologies, could phase in an integrated smart city framework (see Table 4) that is viewed much more as part of a long-term solution to pervasive global changes in human societies, including urbanization, climate change, urban inequality, and digitization agendas.

\section{Conclusions}

What can a polycentric paradigm offer energy infrastructure governance in cities? In this chapter, a polycentric strategy, which connects and align scales, responsibilities, and actors, has been described and proposed as an alternative pathway for energy governance in smart cities Historically, cities were mostly centrally governed, but rising contemporary challenges highlighted in this chapter have upended the need for multiple domains of authority governing. This new mode of governance is characterized by adaptive management, new dynamics of techno-economic networks and multilevel, polycentric and multi-layered governance of energy decisions. 
A key message of this chapter was to analyze the significance of socio-technical systems for deep decarbonization in a way that simultaneously promotes polycentric authority. This approach promotes accountability, inclusivity, innovation, trustworthiness, bottom-up learning, adaptation, and multiple levels of cooperation across sectors and scales. It also embeds flexibility, agility, cultural discourse and social acceptance, systems-oriented design, and equity at multiple scales, all which are fundamental to operationalizing socio-technical energy transitions.

While a polycentric perspective is a offered to rethink the governance of urban energy infrastructure, the existing energy systems and utility business models are changing simultaneously in several cities with respect to diversity, planning, and customer choices. As a result, this requires careful political attention to the technological, regulatory, infrastructure, user-design practices and markets, maintenance and supply networks, and social consequences of the energy transitions. Climate change, demand for modern energy services, outmoded and aging power grid, and rising cost of energy are some of the drivers of this transformation. As a major source of carbon emissions, the electricity sector is also facing regulatory pressure to transition in a manner that limits stranded assets and risk of locked-in technological systems. A polycentric smart energy governance promotes a bottom-up continuous incremental change, in which lock-in problems are reduced because outlived technologies are phased out in a manner that complements model-based analysis with socio-technical policy-oriented solutions.

The approach to urban energy system governance described here acknowledges the role of smart grids in fostering climate resilience and robustness in cities. This strategy, in part, incorporates "hardening" of urban infrastructure to withstand extreme weather events as well as in certain circumstances the option to relocate certain infrastructure services to less vulnerable locations. Moreover, advances in smart grid networks and energy infrastructure systems, including smart meters, DER generation, EVs, demand response, energy storage, and V2G technologies as well as integration of these solutions across urban sectors and scale, mean that the number of actors involved is likely to increase, and so does the complexity of regulation and governance system. Such complex systems call for shared learning, experimentation, information sharing across scales and jurisdictions, greater accountability and transparency, and flexibility in order to deal with uncertain, unpredictable, and nonlinear forms of economic, social, and environmental interruptions. Additionally, adapting and developing smart grid systems in cities require reliable and state-ofthe-art energy supply and demand datasets and related infrastructure services transportation, housing, water, mobility, and ICT services. Although full adaptation is an ongoing challenge for city management, public and private sector service providers, local businesses, residents, and other stakeholders, deepening and aligning polycentrism across sectors and scales underpins the development and implementation of smart energy frameworks that are sociopolitically acceptable, cost-effective, and coevolutionary with technologies and societal development. 


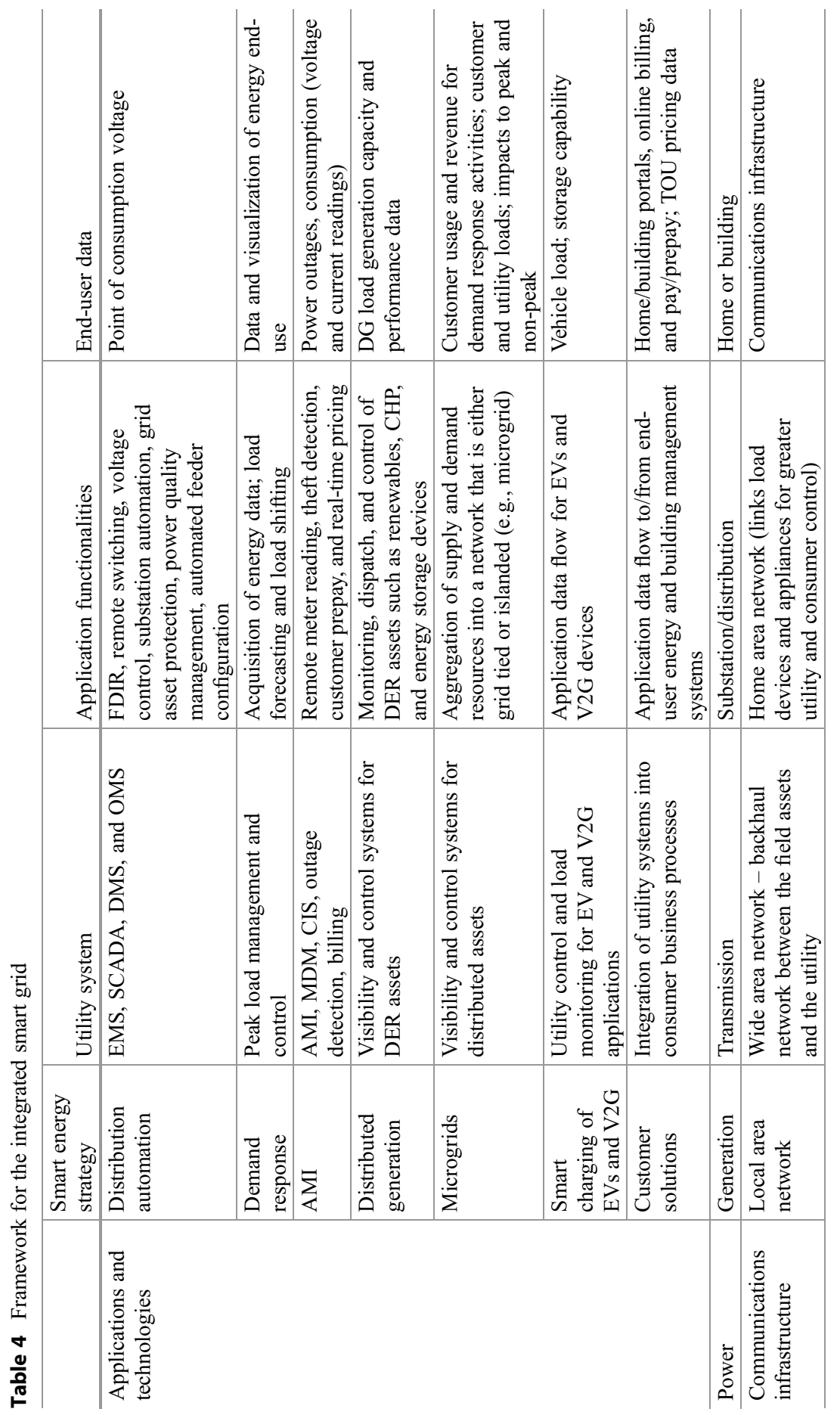




\section{Cross-References}

Smart Cities: Overview and Glossary

\section{References}

Agbemabiese, L., Nyangon, J., Lee, J. S., \& Byrne, J. (2018). Enhancing climate finance readiness: A review of selected investment frameworks as tools of multilevel governance. Center for Energy \& Environmental Policy, University of Delaware. SSRN Electronic Journal. http://doi. org $/ 10.2139 / \mathrm{ssrn} .3082542$.

Aligica, P., \& Tarko, V. (2012). Polycentricity: From Polanyi to Ostrom, and beyond. Governance, 25(2), 237-262.

Alizadeh, T. (2017). An investigation of IBM's Smarter Cites Challenge: What do participating cities want? Cities, 63, 70-80. https://doi.org/10.1016/j.cities.2016.12.009

ASCE. (2017). The 2017 infrastructure report card: Energy. Reston: American Society of Civil Engineers (ASCE). ID: 4990453400. http://www.infrastructurereportcard.org/wp-content/ uploads/2017/01/Energy-Final.pdf

Ascione, F., Bianco, N., De Masi, R. F., Mauro, G. M., \& Vanoli, G. P. (2017). Resilience of robust cost-optimal energy retrofit of buildings to global warming: A multi-stage, multi-objective approach. Energy and Buildings, 153, 150-167.

Bartos, M. D., \& Chester, M. V. (2014). The conservation nexus: Valuing interdependent water and energy savings in Arizona. Environmental Science \& Technology, 48(4), 2139-2149.

Beires, P., Vasconcelos, M. H., Moreira, C. L., \& Peças Lopes, J. A. (2018). Stability of autonomous power systems with reversible hydro power plants: A study case for large scale renewables integration. Electric Power Systems Research, 158, 1-14.

Biesbroek, R., \& Lesnikowski, A. (2018). Adaptation: The neglected dimension of polycentric climate governance? In A. Jordan, D. Huitema, H. V. Asselt, \& J. Forster (Eds.), Governing climate change: Polycentricity in action? (p. 308). Cambridge, UK: Cambridge University Press.

Bisello, A., \& Vettorato, D. (2018). Multiple benefits of smart urban energy transition. In P. Droege (Ed.), Urban energy transition: Renewable strategies for cities and regions (pp. 467-490). London: Elsevier. https://doi.org/10.1016/B978-0-08-102074-6.00037-1. ISBN: 9780081020746.

Blunt, K., \& Gold, R. (2019). PG\&E files for bankruptcy following California wildfires. Wall Street Journal. Retrieved from https://www.wsj.com/articles/pg-e-files-for-bankruptcy-following-cali fornia-wildfires-11548750142

Bulkeley, H., \& Castán Broto, V. (2013). Government by experiment? Global cities and the governing of climate change. Transactions of the Institute of British Geographers, 38(3), 361-375.

Burch, S., Gupta, A., Inoue, C., Kalfagianni, A., Persson, A., Gerlak, A. K., Ishii, A., Patterson, J., Pickering, J., Scobie, M., van der Heijden, J., Vervoort, J., Adler, C., Bloomfield, M., Djalante, R., Dryzek, J., Galaz, V., Gordon, C., Harmon, R., Jinnah, S., Kim, R. E., Olsson, L., van Leeuwen, J., Ramasar, V., Wapner, P., \& Zondervan, R. (2019). New directions in earth system governance research. Earth System Governance, 1, 100006.

Burger, S., Jenkins, J., Huntington, S., \& Pérez-Arriaga, I. (2019). Why distributed? A critical review of the tradeoffs between centralized and decentralized resources. IEEE Power \& Energy, 17(2), 16-24.

Burillo, D., Chester, M. V., Pincetl, S., \& Fournier, E. (2019). Electricity infrastructure vulnerabilities due to long-term growth and extreme heat from climate change in Los Angeles County. Energy Policy, 128, 943-953. 
Byrne, J., \& Taminiau, J. (2018). Utilizing the urban fabric as the solar power plant of the future. In P. Droege (Ed.), Urban energy transition (2nd ed., pp. 31-49). New York City: Elsevier.

Capano, G., \& Woo, J. J. (2017). Resilience and robustness in policy design: A critical appraisal. Policy Sciences: Integrating Knowledge and Practice to Advance Human Dignity, 50(3), 399-426.

Chhetri, P., Han, J. H., Chandra, S., \& Corcoran, J. (2013). Mapping urban residential density patterns: Compact city model in Melbourne, Australia. City, Culture and Society, 4(2), 77-85.

Chiu, R. L. H. (2012). Urban sustainability and the urban forms of China's leading mega cities: Beijing, Shanghai and Guangzhou. Urban Policy and Research, 30(4), 359-383.

Choudhary, B. K., Tripathi, A. K., \& Rai, J. (2019). Can 'poor' cities breathe: Responses to climate change in low-income countries. Urban Climate, 27, 403-411.

Clark, S. S., Chester, M. V., Seager, T. P., \& Eisenberg, D. A. (2019). The vulnerability of interdependent urban infrastructure systems to climate change: Could Phoenix experience a Katrina of extreme heat? Sustainable and Resilient Infrastructure, 4(1), 21-35.

Cortekar, J., \& Groth, M. (2015). Adapting energy infrastructure to climate change - Is there a need for government interventions and legal obligations within the German "Energiewende"? Energy Procedia, 73, 12-17.

d'Alençon, A. P., Smith, H., Álvarez de Andrés, E., Cabrera, C., Fokdal, J., Lombard, M., Mazzolini, A., Michelutti, E., Moretto, L., \& Spire, A. (2018). Interrogating informality: Conceptualisations, practices and policies in the light of the new urban agenda. Habitat International, 75, 59-66.

Davoudi, S. (2012). Resilience: A bridging concept or a dead end? Planning Theory \& Practice, 13(2), 299.

de Jong, P., Barreto, T. B., Tanajura, C. A. S., Kouloukoui, D., Oliveira-Esquerre, K. P., Kiperstok, A., \& Torres, E. A. (2019). Estimating the impact of climate change on wind and solar energy in Brazil using a South American regional climate model. Renewable Energy, 141, 390-401.

DeRolph, C. R., McManamay, R. A., Morton, A. M., \& Nair, S. S. (2019). City energysheds and renewable energy in the United States. Nature Sustainability, 2(5), 412-420.

Du, K., \& Li, J. (2019). Towards a green world: How do green technology innovations affect total-factor carbon productivity. Energy Policy, 131, 240-250.

Duncan, N. B. (1995). Capturing flexibility of information technology infrastructure: A study of resource characteristics and their measure. Journal of Management Information Systems, 12(2), $37-57$.

Eid, C., Codani, P., Perez, Y., Reneses, J., \& Hakvoort, R. (2016). Managing electric flexibility from distributed energy resources: A review of incentives for market design. Renewable and Sustainable Energy Reviews, 64, 237-247.

Emodi, N. V., Chaiechi, T., \& Beg, A. B. M. R. A. (2019). The impact of climate variability and change on the energy system: A systematic scoping review. Science of the Total Environment, $676,545-563$.

Ewing, R., Tian, G., Lyons, T., \& Terzano, K. (2017). Trip and parking generation at transit-oriented developments: Five US case studies. Landscape and Urban Planning, 160(3), 69-78.

Farhangi, H. (2010). The path of the smart grid. IEEE Power and Energy Magazine, 8(1), 18-28.

Faruqui, A., \& Leyshon, K. (2017). Fixed charges in electric rate design: A survey. The Electricity Journal, 30(10), 32-43.

Farzan, F., Lahiri, S., Kleinberg, M., Gharieh, K., Farzan, F., \& Jafari, M. (2013). Microgrids for fun and profit: The economics of installation investments and operations. IEEE Power and Energy Magazine, 11(4), 52-58.

Field, B. G. (1999). The morphology of planning in an urban laboratory. Property Management, 17(2), 139-156.

Fischedick, M., Byrne, J., Hermwille, L., Taminiau, J., Luhmann, H., Stelzer, F., \& Vallentin, D. (2018). Reflections on the state of climate change policy: From COP21 to cities. In S. Lele, E. S. Brondizio, J. Byrne, G. M. Mace, \& J. Martinez-Alier (Eds.), Rethinking environmentalism: Linking justice, sustainability, and diversity. Cambridge, MA: MIT Press. ISBN: 9780262038966. 
Fox-Penner, P. S. (2010). Smart power: Climate change, the smart grid, and the future of electric utilities (1st ed.). Washington, DC: Island Press. ISBN: 9781597267052.

Habitat III. (2019). New urban agenda. http://habitat3.org/the-new-urban-agenda/. Accessed 30 July 2019.

Hakelberg, L. (2014). Governance by diffusion: Transnational municipal networks and the spread of local climate strategies in Europe. Global Environmental Politics, 14(1), 107-129.

Hall, P. G., \& Pain, K. (2006). The polycentric metropolis: Learning from mega-city regions in Europe. Sterling: Earthscan. ISBN: 9781844073290.

Hiremath, R. B., Balachandra, P., Kumar, B., Bansode, S. S., \& Murali, J. (2013). Indicator-based urban sustainability - A review. Energy for Sustainable Development, 17(6), 555-563.

Hoarau, Q., \& Perez, Y. (2019). Network tariff design with prosumers and electromobility: Who wins, who loses? Energy Economics, 83, 26-39.

Hölscher, K., Frantzeskaki, N., McPhearson, T., \& Loorbach, D. (2019). Tales of transforming cities: Transformative climate governance capacities in New York City, U.S. and Rotterdam, Netherlands. Journal of Environmental Management, 231, 843-857.

Hudalah, D., \& Firman, T. (2012). Beyond property: Industrial estates and post-suburban transformation in Jakarta Metropolitan Region. Cities, 29(1), 40-48.

Hughes, L. (2015). The effects of event occurrence and duration on resilience and adaptation in energy systems. Energy, 84, 443-454.

Hussain, A., Bui, V., \& Kim, H. (2019). Microgrids as a resilience resource and strategies used by microgrids for enhancing resilience. Applied Energy, 240, 56-72.

Johnson, S. (2001). Emergence: The connected lives of ants, brains, cities, and software. New York: Scribner. ISBN: 9780684868752.

Jones, C. \& Kammen, D. M. (2014) Spatial Distribution of U.S. Household Carbon Footprints Reveals Suburbanization Undermines Greenhouse Gas Benefits of Urban Population Density. Environmental Science \& Technology, 48(2), 895-902

James, P., Astoria, R., Castor, T., Hudspeth, C., Olstinske, D., \& Ward, J. (2020). Smart Cities: Fundamental Concepts. In Handbook of Smart Cities, J.C. Augusto (Ed.). London: Springer

Jordan, A. J., Huitema, D., Hildén, M., van Asselt, H., Rayner, T. J., Schoenefeld, J. J., Tosun, J., Forster, J., \& Boasson, E. L. (2015). Emergence of polycentric climate governance and its future prospects. Nature Climate Change, 5(11), 977-982.

Kanger, L., Geels, F. W., Sovacool, B., \& Schot, J. (2019). Technological diffusion as a process of societal embedding: Lessons from historical automobile transitions for future electric mobility. Transportation Research Part D: Transport and Environment, 71, 47-66.

Kennedy, C. A., Stewart, I., Facchini, A., Cersosimo, I., Mele, R., Chen, B., Uda, M., Kansal, A., Chiu, A., Kim, K., Dubeux, C., Lebre La Rovere, E., Cunha, B., Pincetl, S., Keirstead, J., Barles, S., Pusaka, S., Gunawan, J., Adegbile, M., Nazariha, M., Hoque, S., Marcotullio, P. J., González Otharán, F., Genena, T., Ibrahim, N., Farooqui, R., Cervantes, G., \& Sahin, A. D. (2015). Energy and material flows of megacities. Proceedings of the National Academy of Sciences of the United States of America, 112(19), 5985-5990. https://doi.org/10.1073/pnas.1504315112

Keohane, R. O., \& Victor, D. G. (2011). The regime complex for climate change. Perspectives on Politics, 9(1), 7-23.

Kim, J., \& Larsen, K. (2017). Can new urbanism infill development contribute to social sustainability? The case of Orlando, Florida. Urban Studies, 54(16), 3843-3862.

Kuiken, D., \& Más, H. F. (2019). Integrating demand side management into EU electricity distribution system operation: A Dutch example. Energy Policy, 129, 153-160.

Lam, P., Chan, E., Poon, C., Chau, C., \& Chun, K. (2010). Factors affecting the implementation of green specifications in construction. Journal of Environmental Management, 91(3), 654-661.

Lee, S. K., Kwon, H. R., Cho, H., Kim, J., \& Lee, D. (2016). International case studies of smart cities Songdo, Republic of Korea. Inter-American Development Bank. Washington, D.C.

Levin, K., Cashore, B., Bernstein, S., \& Auld, G. (2012). Overcoming the tragedy of super wicked problems: Constraining our future selves to ameliorate global climate change. Policy Sciences, $45(2), 123-152$. 
Li, Y., Xiong, W., \& Wang, X. (2019). Does polycentric and compact development alleviate urban traffic congestion? A case study of 98 Chinese cities. Cities, 88, 100-111.

Lightner, E. M., \& Widergren, S. E. (2010). An orderly transition to a transformed electricity system. IEEE Transactions on Smart Grid, 1(1), 3-10.

MacLeod, G. (2013). New urbanism/smart growth in the Scottish highlands. Urban Studies, 50(11), 2196-2221.

Maki, S., Chandran, R., Fujii, M., Fujita, T., Shiraishi, Y., Ashina, S., \& Yabe, N. (2019). Innovative information and communication technology (ICT) system for energy management of public utilities in a post-disaster region: Case study of a wastewater treatment plant in Fukushima. Journal of Cleaner Production, 233, 1425-1436.

Markolf, S. A., Hoehne, C., Fraser, A., Chester, M. V., \& Underwood, B. S. (2019). Transportation resilience to climate change and extreme weather events - Beyond risk and robustness. Transport Policy, 74, 174-186.

Martinez-Alier, J., Temper, L., Del Bene, D., \& Scheidel, A. (2016). Is there a global environmental justice movement? The Journal of Peasant Studies, 43(3), 731-755.

Martišauskas, L., Augutis, J., \& Krikštolaitis, R. (2018). Methodology for energy security assessment considering energy system resilience to disruptions. Energy Strategy Reviews, 22, $106-118$.

Miller, J. D., \& Hutchins, M. (2017). The impacts of urbanisation and climate change on urban flooding and urban water quality: A review of the evidence concerning the United Kingdom. Journal of Hydrology: Regional Studies, 12, 345-362.

Mumford, L. (1938). The culture of cities. New York: Harcourt Brace and Company.

Nyangon, J. (2017). Distributed energy generation systems based on renewable energy and natural gas blending: New business models for economic incentives, electricity market design and regulatory innovation. Ph.D. Dissertation. Energy and Environmental Policy, College of Engineering, University of Delaware.

Smith, A., Lott, N., Houston, T., Shein, K., Crouch, J., Enloe, J. (2019). Billion-dollar weather and climate disasters (2019). National Oceanic and Atmospheric Administration (NOAA), National Centers for Environmental Information. Washington, D.C. https:/www.ncdc.noaa.gov/billions/ events.pdf

Noel, L., Papu Carrone, A., Jensen, A. F., Zarazua de Rubens, G., Kester, J., \& Sovacool, B. K. (2019). Willingness to pay for electric vehicles and vehicle-to-grid applications: A Nordic choice experiment. Energy Economics, 78, 525-534.

Noland, R. B., Weiner, M. D., DiPetrillo, S., \& Kay, A. I. (2017). Attitudes towards transit-oriented development: Resident experiences and professional perspectives. Journal of Transport Geography, 60, 130-140.

Nyangon, J. (2014). International environmental governance: Lessons from UNEA and perspectives on the post-2015 era. Journal of Sustainable Development Law and Policy (The), 4(1), 174-202.

Nyangon, J., \& Byrne, J. (2018). Diversifying electricity customer choice: REVing up the New York energy vision for polycentric innovation. In P. V. Tsvetkov (Ed.), Energy systems and environment (pp. 3-23). London: IntechOpen. https://doi.org/10.5772/intechopen.76023.

Nyangon, J., Alabbas, N., \& Agbemabiese, L. (2017a). Entangled systems at the energy-water-food nexus: Challenges and opportunities. In P. Rao \& Y. Patil (Eds.), Reconsidering the impact of climate change on global water supply, use, and management (pp. 145-165). Hershey: IGI Global.

Nyangon, J., Byrne, J., \& Taminiau, J. (2017b). An assessment of price convergence between natural gas and solar photovoltaic in the U.S. electricity market. Wiley Interdisciplinary Reviews: Energy and Environment, 6(3), 1-20.

Nykvist, B., \& Nilsson, M. (2015). Rapidly falling costs of battery packs for electric vehicles. Nature Climate Change, 5(4), 329-332.

Nykvist, B., Sprei, F., \& Nilsson, M. (2019). Assessing the progress toward lower priced long range battery electric vehicles. Energy Policy, 124, 144-155. 
Oprea, V. S., Bâra, A., \& Ifrimb, G. (2018). Flattening the electricity consumption peak and reducing the electricity payment for residential consumers in the context of smart grid by means of shifting optimization algorithm. Computers \& Industrial Engineering, 122, 125-139.

Ostrom, E. (2010). A long polycentric journey. Annual Review of Political Science, 13, 1-23.

Pallonetto, F., De Rosa, M., Milano, F., \& Finn, D. P. (2019). Demand response algorithms for smart-grid ready residential buildings using machine learning models. Applied Energy, 239(1), $1265-1282$.

Papadopoulos, S., \& Kontokosta, C. E. (2019). Grading buildings on energy performance using city benchmarking data. Applied Energy, 233-234, 244-253.

Pasichnyi, O., Wallin, J., \& Kordas, O. (2019). Data-driven building archetypes for urban building energy modelling. Energy, 181, 360-377.

Pérez-Arriaga, I., \& Knittel, C. (2016). Utility of the future: An MIT energy initiative response to an industry in transition. Boston: MIT Energy Initiative.

Pires, S. M., Fidélis, T., \& Ramos, T. B. (2014). Measuring and comparing local sustainable development through common indicators: Constraints and achievements in practice. Cities, $39,1-9$.

Prinsloo, G., Mammoli, A., \& Dobson, R. (2016). Discrete cogeneration optimization with storage capacity decision support for dynamic hybrid solar combined heat and power systems in isolated rural villages. Energy, 116, 1051-1064.

Radzi, A. (2018). The 100\% renewable energy metropolis: Governing the design of cities for renewable energy infrastructures. In P. Droege (Ed.), Urban energy transition (pp. 85-113). London: Elsevier. https://doi.org/10.1016/B978-0-08-102074-6.00023-1. ISBN: 9780081020746.

Rattanachot, W., Wang, Y., Chong, D., Suwansawas, S. (2015). Adaptation strategies of transport infrastructures to global climate change. Transport Policy 41, 159-166. https://doi.org/10.1016/ j.tranpol.2015.03.001

Revi, A., Satterthwaite, D. E., Aragón-Durand, F., Corfee-Morlot, J., Kiunsi, R. Z. R., Pelling, M., Roberts, D. C., Solecki, W., Silva, J., Dodman, D., Maskrey, A., Gajjar, S. P., Tuts, R., Balbus, J., Cardona, O. D., \& Sverdlik, A. (2014). Urban Areas. In C. B. Field, V. R. Barros, D. J. Dokken, K. J. Mach, M. D. Mastrandrea, T. E. Bilir, M. Chatterjee, K. L. Ebi, Y. O. Estrada, R. C. Genova, B. Girma, E. S. Kissel, A. N. Levy, ... L. L. White (Eds.), Climate change 2014 impacts, adaptation, and vulnerability part A: Global and sectoral aspects. contribution of working group II to the fifth assessment report of the intergovernmental panel on climate change (pp. 535-580). Cambridge, UK/New York: Cambridge University Press.

Sircar, I., Sage, D., Goodier, C., Fussey, P., \& Dainty, A. (2013). Constructing resilient futures: Integrating UK multi-stakeholder transport and energy resilience for 2050. Futures, 49, 49-63.

Spaans, M., \& Waterhout, B. (2017). Building up resilience in cities worldwide - Rotterdam as participant in the 100 Resilient Cities programme. Cities, 61, 109-116.

STAR Communities. (2015). Technical guide to STAR Community rating system V. 1.2. Washington, DC: STAR Communities. https://reporting.starcommunities.org/shop/product/10020130306

STAR Communities. (2017). Leading STAR Community indicators. Washington, DC: STAR Communities. https://reporting.starcommunities.org/uploads/Leading-Indicators-bro chure-Final.pdf

Taminiau, J., Nyangon, J., Lewis, A. S., \& Byrne, J. (2017). Sustainable business model innovation: Using polycentric and creative climate change governance. In Z. Fields (Ed.), Collective creativity for responsible and sustainable business practice (pp. 140-159) IGI Global.

Taminiau, J., Banks, J. P., Bleviss, D., \& Byrne, J. (2019). Advancing transformative sustainability: A comparative analysis of electricity service and supply innovators in the United States. Wiley Interdisciplinary Reviews: Energy and Environment, 8(4), e337.

Taylor, M. A., Philp, M. L. (2015). Investigating the impact of maintenance regimes on the design life of road pavements in a changing climate and the implications for transport policy. Transport Policy 41, 117-135. https://doi.org/10.1016/j.tranpol.2015.01.005 
Trencher, G., \& van der Heijden, J. (2019). Instrument interactions and relationships in policy mixes: Achieving complementarity in building energy efficiency policies in New York, Sydney and Tokyo. Energy Research \& Social Science, 54, 34-45.

U.S. Department of Energy. (2015). Quadrennial energy review: Energy transmission, storage, and distribution infrastructure. Washington, DC: United States Department of Energy (DOE).

Underwood, B. S., Guido, Z., Gudipudi, P., \& Feinberg, Y. (2017). Increased costs to US pavement infrastructure from future temperature rise. Nature Climate Change, 7, 704.

United Nations. (2014). World urbanization prospects: The 2014 revision, highlights (ST/ESA/SER. A/352). United Nations, Department of Economic and Social Affairs, Population Division. New York (USA)

Varma, R., \& Sushil. (2019). Bridging the electricity demand and supply gap using dynamic modeling in the Indian context. Energy Policy, 132, 515-535.

Wang, Y., Lin, H., Liu, Y., Sun, Q., \& Wennersten, R. (2018). Management of household electricity consumption under price-based demand response scheme. Journal of Cleaner Production, 204, 926-938.

Wang, H., Wang, S., \& Tang, R. (2019). Development of grid-responsive buildings: Opportunities, challenges, capabilities and applications of HVAC systems in non-residential buildings in providing ancillary services by fast demand responses to smart grids. Applied Energy, 250(1), 697-712.

Washom, B., Dilliot, J., Weil, D., Kleissl, J., Balac, N., Torre, W., \& Richter, C. (2013). Ivory tower of power: Microgrid implementation at the University of California, San Diego. IEEE Power and Energy Magazine, 11(4), 28-32.

Weina, D., Gilli, M., Mazzanti, M., \& Nicolli, F. (2016). Green inventions and greenhouse gas emission dynamics: A close examination of provincial Italian data. Environmental Economics and Policy Studies, 18(2), 247-263.

Wey, W., \& Hsu, J. (2014). New urbanism and smart growth: Toward achieving a smart National Taipei University District. Habitat International, 42, 164-174.

Wu, F. (1998). Polycentric urban development and land-use change in a transitional economy: The case of Guangzhou. Environment and Planning A, 30(6), 1077-1100.

Yan, X., Ozturk, Y., Hu, Z., \& Song, Y. (2018). A review on price-driven residential demand response. Renewable and Sustainable Energy Reviews, 96, 411-419.

Youn, H., Strumsky, D., Bettencourt, L., \& Lobo, J. (2015). Invention as a combinatorial process: Evidence from US patents. Journal of the Royal Society Interface, 12(106) 3-6.

Zelli, F., \& Asselt, H. (2013). The institutional fragmentation of global environmental governance: Causes, consequences, and responses. Global Environmental Politics, 13(3), 1-13.

Ziegler, E. H. (2006). China's polycentric regional growth: Shanghai's satellite cities, the automobile, and new urbanism with Chinese characteristics. Georgia State University Law Review, 22, 959-1031.

Zou, Y., Lu, Y., \& Cheng, Y. (2019). The impact of polycentric development on regional gap of energy efficiency: A Chinese provincial perspective. Journal of Cleaner Production, 224, 838-851. 